\title{
I Know Many Songs, But I Cannot Sing Brian Kiteley
}

THE RARE DAY-LONG RAIN fell on the Nile valley north of my wife's parents' country home. During the drive south from Cairo, my daughter Catherine asked me to explain the unusual phenomenon several times. It has rained hard twice in her lifetime. I told her that Europe got all this rain every winter, and because the Europeans were rich and thought they still owned the world, they tried to palm their excess precipitation off on us each year, declaring it part of the IMF package Egypt must accept if we expect to receive more loans. My daughter looked as if she were trying to squeeze this information into her brain. The rain ended in the peasant village a few dozen meters from my in-laws' gate. Their man Ramzi waited for us there, pointing to the clean line of clouds that stopped directly over our heads. Then Ramzi indicated the field of alfalfa to the north, where we could see hard wet rain still falling. "You see," I told my daughter, "the Europeans respect your grandfather. They leave his house dry." The sun was shining on the pool and on the grass in the back yard, slanting from the Libyan Desert like the hand of God. Rain had also fallen on the desert, leaving a great swath of pearl-shaped holes. Two officials from the IMF were listening to my father-in-law describe his plans for new middle class housing in the desert. My daughter and I sat in deck chairs by the pool, patiently awaiting Grandpa's full attention. The four-year-old girl, always busy at something useful, picked pebbles out of a bowl of dried chick peas. The IMF officials stood on the grass. My father-in-law watered both sand and lawn from a long twitching hose. We knew, even though we could not hear him, that George was insisting Egyptians could learn to love the desert if only their government built living, breathing communities there instead of sterile apartment blocks. The IMF stood with their arms crossed and their chins thrust out at the awful emptiness of the Sahara.

A few days after my wife threw me out the fourth or fifth time, her father George began to talk nonstop, mostly in a gentle whisper to himself, sometimes without pausing for breath. I had moved in with my in-laws as I always did. I came in very late one night from play rehearsal to find my mother-in-law Hanaa at the base of the round staircase in her nightgown, a 
candle in her hand, staring up at her husband's study. She described George's mania. I tried to laugh it off, saying we would have more cause to worry if he'd gone silent or if a normally silent man had become suddenly garrulous. She said, "You are absurdly optimistic, Gamal-Leon," sounding for that instant exactly like her daughter. She gave me a parting glance full of some emotional turmoil my shallow mind mistook for sexual longing. When I entered his study, George was talking quietly but dramatically to himself about a set of Nubian villages whose ingeniously energy efficient architecture might have been a model for all of Egypt had George not stumbled on them a few days before Lake Nasser swallowed them forever-I'd heard the story many times. George appeared to conclude, saying, "Maupassant used to eat at the restaurant in the Eiffel Tower because it was the only place in Paris where he did not risk seeing the Eiffel Tower. You see why I'm talking as I do now?" Then as if to illustrate this point, he added, "In the desert, the temperature is always a great deal lower at night and that cold air remains near the ground during the day if you can keep it in shade. The old Arab towns hoarded this coolness in their narrow streets and alleys. But carve rule-straight boulevards through the old cities, and the wind sucks out the chill. You are left at the mercy of the blazing sun. I have done the same thing to my mind, despite my life's goal of preserving the old Arab ways. I built broad straight boulevards, when I should have followed the winding path of my thoughts. I have failed, Gamal-Leon." George and I were sitting quietly, his head on my shoulder, when the doctor arrived with my wife.

Sleep was always the enemy when I was growing up. We lived in a noisy, crowded district of Cairo, where the neighbors' arguments were easier to solve than our own. The cafés my brothers and I frequented were open all night. When I was very young, I put my bedding on the wide window sill to take notes on the Blue Nile coffeehouse. My eldest brother favored this haunt, where joy for life and love of coffee seemed one and the same thing. The nightly celebrations turned to mumbles and yawns only when the sun brushed the sky and the men in the café glared at the streaks of gray in their narrow strip of heaven. Ramadan was the happiest time of my year, even though we were Christian and fatherless. Everyone else in the city joined my war against sleep, at least while it was dark. Women and children also stayed up late then, parading through the streets in search of sweets and 
pancakes and ribbons of delicate dough spun off domes of red hot metal. My wife, years later, stubbornly slept through the night for the month after our baby was born. That first month coincided with Ramadan, and I would sit on the balcony with a small lantern, reading, writing, or taking notes on the neighbors' conversations at parties I could practically touch. The baby would make her tentative gurgles and talk to her thumb, and I. would go inside to roll my still-sleeping wife onto her side. I would free her beautiful breasts and bring the baby to its target, both heart-warming affirmation of parenting and erotic torture. But my wife usually surfaced, irritated that her sleep was being sucked from her, angry with the neighbors for their pagan revelry until all hours, and furious with me for enjoying my insomnia. The introduction of American baby formula to our markets allowed my wife to sleep till morning. My father died one night when I was too young to remember. Except I do remember staying up very late with my brothers, enjoying what my young mind mistook for a happy party, finally falling asleep at dawn with the rosy sense that love was something you found only at the end of a long night of wakefulness.

One night before bed I was telling my daughter an old Armenian fairy tale, acting out several parts, and speaking in Armenian. I used props to turn me into different characters: her security blanket, for a mountain lion; the wire mesh wastebasket, for the King. With my own Basque beret I became the court jester whose jokes and playlets no one wanted to hear anymore. Catherine, a sigh away from sleep, sat upright at this character. She stretched and, as she yawned, brought three fingers daintily down over her mouth, just as her mother did. "Daddy. You aren't supposed to be in this story. It happened a long time ago. How did you get into the story?" Then she curled up and drifted off to sleep. I continued to whisper the tale, entranced by the unraveling of my imagination. She began to snore, a signal she was feigning sleep and wanted me to leave. But I was debating whether to write this story down, sell it in America, get film rights. The problem was my Armenian tales did not translate well into English or Arabic. They lost their alpine grace and playfulness. I told them in Armenian because my Coptic Egyptian wife refused to learn the language. My daughter understood but did not speak it. I also used Armenian to turn the terrible arguments my wife and I had into funny stories. My pale defense for this practice: I was giving my daughter a leg up if, one day, she married a man 
as linguistically schizophrenic as myself. I whispered goodnight in French and left the room. A few steps out the door, I heard my daughter's reply, in the Armenian phrase that began all my bedtime stories to her: "I know many songs, but I cannot sing." I ran back to the doorway, but she was asleep. I could tell by her breathing, a delicate whistle, not the pretend snoring she had made earlier.

"Ayza some badi," she had a habit of saying around the age of two. Ayza is the feminine Egyptian colloquial for "I want." Badi, pronounced "body," is short for zabadi, "yoghurt." We thought this was adorable. She was mixing Arabic and English, but also making a play on words. She meant, early in the morning, that she wanted some yoghurt for breakfast. But she also meant that she wanted somebody to play with, some body to keep her warm, just a body. It was hard not to giggle at this performance, which she repeated dozens of mornings in a row until it was no longer funny, but it was always funny on its own terms. We made the mistake of mentioning it to Wael Barakat, our good friend, Catherine's godfather, and head of the Euro-American advertising agency in Cairo. He went bananas over the possibilities of the phrase. At the time Catherine was still in her angelic phase, prone to taking off her clothes and repeating these words (or other equally precious and pithy phrases) endlessly until you wanted to strangle her. Wael decided to use the three words for a television ad campaign, which he happened to be preparing for Nestlé, who made the yoghurt all the rich Egyptians were eating. Euro-American advertising used blond Euro-American models who sang-dubbed in-catchy tunes that mixed Arabic and English, sometimes in the same word. Wael's first thought was to hire Catherine herself. Aristocrat that she is, my wife refused, but bless her cunning heart she fought Wael like a veteran Hollywood agent for the rights to this phrase, which she copyrighted under his nose the day we had the argument with him over it, by mailing off a postcard to ourselves with the sentence written on it, followed by the copyright symbol. There is no such fastidiousness about patented ideas in Egypt, but Wael loved to mimic all sorts of American behavior. We made 10,000 Egyptian pounds. By the time the commercial arrived on television, over a year later, Catherine was speaking in long complex sentences about God and politics and the transsubstantiation of her doll Nut's soul. When she saw the ad, she burst into tears. She said, "I was never that young, Baba. I feel very used." We 
were alarmed by the last word. We asked if she felt we had exploited her. She knew what "exploited" meant. "No, no, no," she said. "I am not that little girl anymore. She's been used up. She's all gone now. A long time ago, she was used up. I am very old now, you have no idea how old I am."

In a dream my daughter Catherine felt her mother pull one arm and say, "This child is as Egyptian as the sand under the Step Pyramid." Her daddy took the other arm, with a tug, and said, "But this limb feels as Armenian as Arslan, the mountain lion who ate only unbelievers." They held each arm firmly. They pulled. The noise of Catherine coming apart was surprisingly soft, a gentle pop. Now there were two Catherines. But one Catherine awoke hugging herself, very sad she was not twins. She got up and dressed all by herself. It was dark. As she walked down the hall to the dining room she realized her T-shirt was on backwards. Tears welled up in her eyes. She was a girl who liked things in their proper place and threw a fit at the merest hint of chaos. But the feeling of the shirt on backwards was so like being pulled apart that the tears soon dried. The sun was beginning to wake, but like Catherine it had sleep in its eyes, a fog that obscured even the balcony of the building next door, where the big American men laughed too loud and did not clean the dust. Catherine found her parents in the kitchen at the corner of the big metal table Cook chopped chickens on. My wife and I sat on tall stools. We looked funny there, shoulders scrunched up, eyes practically droozed asleep, holding hands! An unschooled observer might assume we were happy ever after. But Catherine knew we were simply too tired to argue anymore about which school to send her to: the German language school (my choice) or the Arabic (my wife's). Catherine left the doorway. It is hard to say whether my wife or I actually saw her. My balcony garden beckoned, my exotic African plants. Catherine stood in the swirl of smells. Deh-deh, our maid, would not arrive for another hour, too long. A plant spoke to her: "Eat me."

"But what if you are poison?" she said.

"You read Alice in Wonderland all by yourself and you're only four years old," said the plant. "You know how the story turns out."

We live next door to an American oil exploration company. I sit out on my balcony overlooking the Nile in the morning before the sun rises too high and sip my wife's exquisite Turkish coffee and listen to the general manager 
of the oil company argue with his partner. I watch them arrive every morning in identical Jeep Cherokees. They live a few blocks from each other in the same suburb, but it never occurs to them to ride together in one vehicle. Both are huge men in the shoulders with skinny legs. One is from Denver, the other from Fort Worth. Denver and Fort Worth disagree over just about everything, but most often about how to treat Egyptians, both at the office and in the field. Denver is no Lawrence of Arabia, but he does speak kindly to his staff and has even made a friend of his chief surveyer, Gaber, a master at computers and a genius at keeping the machines alive despite the fickle currents of Egyptian electricity. Fort Worth calls Egyptians "Niggers" behind their backs. He rails against their circular thinking and their endless coffee breaks. But he is afraid to be in the building alone with them. One morning Fort Worth was on the phone to Denver, who was home with food poisoning. I was less than five feet from Denver's desk, which Fort Worth appropriates whenever his partner is absent, feeling maybe he is safer in the kinder man's office. Denver also has a balcony, dusty from disuse. It is an easy crawl from my balcony. Our buildings are side by side facing the Nile. Fort Worth had been alone in the office two hours that day, calling Denver every few minutes with increasingly pathetic and inconsequential questions. Denver hung up on him the last time, but I could tell-don't ask how-Fort Worth kept talking to the dead line. He was confiding to the dead line that the key to prophylaxis in Egypt is to drink an American beer with the juice of one lemon before every meal, even breakfast. I slipped onto his balcony and studied him through the blinds. He had painted half of the black telephone with White-Out, the now obsolete correcting fluid. The computer screen at his elbow was flashing the words, "NO END IF."

Kimball Johnson of Fort Worth, Texas was at his office next door to our apartment very early that morning because of an overnight flight from Kuwait. I reconstruct all this from a few laconic sentences he told me. Instead of going home to Ma'adi-Johnson was too keyed up to sleep-he went directly to Zamalek. Then, as he was spreading out a map of a south Sinai oil field, the odor of ambergris wafted in through the window. Johnson does not have an acute sense of smell. That's his wife Leslee's department. Inside her airtight BMW she can detect a cigarette smoker in the car ahead of them at 60 miles an hour. This is why the scent upset 
Kimball Johnson: The woman next to him on the plane from Kuwait had shown him a nugget of ambergris during a forgettable conversation. This lump of whale intestinal matter set something off deep in Johnson. Before smelling it, he had been only partly involved in the conversation with the bookseller from London (his mind was also comparing equipment replacement costs using Bombay versus Piraeus suppliers). The instant after a whiff of this powerful, sweet, sexy, rancid odor-like Playdoh-his attention focused completely on his neighbor. She was not all that pretty. She had a large horsey face, her skin wasn't good, hair thin and wispy, hips too wide for Johnson's taste, which ran, in his private and pathetic fantasies to very young teenage girls. But with an intensity he'd never before experienced-he had not once in his marriage even considered cheating on Leslee-he found himself wounded to the quick by this British woman's beauty and charm and indirectness. Nothing happened. They parted with a tepid handshake, without exchanging names. Then from his partner's office, he smelled the musky ambergris again. Something told him to act. He had never been on the balcony before. For a moment a dust storm on the horizon distracted him. Somewhere nearby was what sounded like a creaking shutter, but there was no wind. Finally he spied on the floor of the balcony next door the twisted, convulsing body of my daughter, vomiting but otherwise strangely quiet. Johnson bounded across the terrifying abyss of twelve floors and scooped up the little girl, grabbed the half-eaten leaf beside her, and thundered into the many-roomed apartment looking for us. His big Jeep took the three of us to the American hospital. His connections and intimidating American presence sped us past the bureaucracy of the front desk into the emergency room. Then it was as if it had never happened. My wife and Catherine were asleep in the hospital room, and Kimball Johnson was asking me why he might have smelled ambergris on my daughter. Her clothes were draped over my arm. I lifted her T-shirt, and my little blue plastic container of ambergris fell to the floor. "She must have nicked it from my bathroom this morning," I said. "I used some after shaving last night before we went to a party." Her little body crushed the container when she fell. Opened even a crack, the scent fills the air. Humans can smell one millionth of a part a dozen yards away because it so closely resembles human pheromones. Kimball Johnson was crying. In a hoarse whisper, he said, "You will surely despise me, but I might have left her laying there, had her skirt not shimmied up her bottom when she fell. She 
was not wearing any undergarments. I would be lying, sir, if I said I jumped onto your balcony only to save her life." 